Article

\title{
The Manifestation of Neighborhood Effects: A Pattern for Community Growth?
}

\author{
Michael R. Cope *, Jorden E. Jackson, Scott R. Sanders, Lance D. Erickson, Tippe Morlan and \\ Ralph B. Brown
}

Department of Sociology, Brigham Young University, Provo, UT 84602, USA; jacksjor@byu.edu (J.E.J.); scott_sanders@byu.edu (S.R.S.); lance_erickson@byu.edu (L.D.E.); beatricemorlan@gmail.com (T.M.); ralph.browning.brown@gmail.com (R.B.B.)

* Correspondence: michaelrcope@byu.edu

Received: 27 December 2019; Accepted: 25 January 2020; Published: 5 February 2020

\begin{abstract}
Neighborhood effects, or the development of community by neighborhoods, are often studied in an urban context. Previous research has neglected to examine the influence of neighborhoods in nonurban settings. Our case study, however, contributes to the existing literature as it takes place in a small, rural-to-urban town at an important point in time where the town was urbanizing. We find that neighborhood effects also influence community satisfaction and attachment in Creekdale, an urbanizing town. Using survey data $(N=1006)$ drawn from the Creekdale Community Citizens Viewpoint Survey (CCVS), we find that, contrary to conventional wisdom, population size and density does not matter necessarily for an individual's community attachment and satisfaction; community experience is shaped by neighborhood effects.
\end{abstract}

Keywords: community; neighborhood effects; attachment; satisfaction; development

\section{Introduction}

To what degree are size, density, and community organization indicators of neighborhood effects on residents' sense of community? We show that the development of community by neighborhoods is not just an urban phenomenon, but rather that rural and small towns also develop community via neighborhoods. Problems commonly experienced in urban areas dominate the literature of community and neighborhood effects, stemming from the development of the Chicago School of Human Ecology [1-8]. In fact, the idea of living in a smaller place is automatically correlated with the presence of one large community: "the assumed connection of rural towns with community was often supported by social experience, and it was universally compatible with small town mythology that has been so influential in American history" [9] (p. 10). Thus, it has long been assumed that the experience of community manifests differently in small towns and in urban areas.

However, by examining the presence of neighborhood differentiation within a small and growing town, we show in our case study that community is created via the same social processes that are theorized to occur in urban neighborhoods. Therefore, we argue that the total population size does not necessarily matter in the development of community. Rather, it is the neighborhood effects that significantly influence measures of community experience.

Beginning with Wirth's foundational 1938 article, "Urbanism as a Way of Life," and until 1974 with Kasarda and Janowitz's article on community attachment, community research has been characterized by the assumption that population size and density matter in how communities are formed [10-12]. Based on the Wirthian tradition, urban areas were characterized as places where secondary contacts replace primary contacts, bonds of kinship are weak, and neighborhoods disappear [6,13-15]. In the 
twentieth century, as cities were urbanizing and industrializing, widespread concern for the state of urban life nurtured the trend of an urban, as opposed to rural, perspective in community studies [1-8].

The character of community within cities is a widely debated issue, as scholars dispute whether community has been lost [1,6,16,17], saved [18-30], or liberated [31-42]. The heart of this debate lies in defining the most significant characteristics in the development of community: 1. population size and density or 2. community organization, networks, and length of residence (i.e., newcomers will not feel as at home in their community compared to old-timers) [38,43]. If Kasarda and Janowitz are correct in believing that population size does not matter and that length of residence and affective connection to a place do, we expect to see, as new neighborhoods emerge in small towns, with newcomers moving into new neighborhoods, that the neighborhoods become important variables within rural, urbanizing, and urban communities.

Fundamentally, modernity is characterized by individualism [44-46]. With the rise of globalization and specialization, individualism conquers collectivism, and this is apparent even within established communities [46]. According to Bauman, society "has undergone a process of individualization. Troubles are supposed to be suffered and coped with alone and are singularly unfit for cumulation into a community of interests which seeks collective solutions to individual troubles" [44] (p. 86, original emphasis). That is to say, in pre-modern societies, solutions to uncertainty, that is job loss, illness, a family death, were rooted in existing communities, whereas the modern world has made the old-community-oriented-solutions either unavailable or unattractive, which leads to recreating the stability of community membership in different ways [46]. We can thus expect the way residents experience community to reflect this trend, particularly through the social processes manifested in neighborhoods, such as neighborhood selection by a predominant race, e.g., [47], socioeconomic background, e.g., [48], a desirable commuting zone, e.g., [49], or the employment and shopping opportunities in a particular place, e.g., [50].

If Bauman's critique of modern life is valid, and this individualism is apparent in larger cities and communities [51,52], it begs the question about whether neighborhood selection by a predominant race or socioeconomic background, for example, are also apparent in smaller communities. Although the research shows the many pathways by which context influences an individual's experience of community within urban communities $[6,53,54]$, the literature on individuals within rural and urbanizing communities is scarce. To the extent that individualism is a template for people's experiences in large cities and small towns, researchers should expect to find the same results occurring in smaller rural urbanizing communities as well; in other words, the population size of geographic locale should not matter for neighborhood effects to emerge. However, despite the work of academics such as Kasarda and Janowitz to move community research away from the Wirthian tradition, community is still primarily analyzed in an urban context, perpetuating the idea that population size matters [38,43]. This neglect of individuals within small communities and any neighborhood effects which are present drives our methodological inquiry. To understand community as it manifests and is experienced in small rural/urbanizing towns, our study examines the neighborhoods in Creekdale ${ }^{1}$, a small town in the western United States.

\subsection{Linear Development Model and Systemic Model}

Past literature has analyzed community using both the linear development model and the systemic model of community attachment $[38,43,55]$. The linear development model reflects the idea that "linear increases in the population size and density of human communities are assumed to be the primary exogenous factors influencing patterns of social behavior" [38] (p. 328). This model, rooted in the work of Wirth [6], examines social change through the lens of modernization, a phenomenon which inevitably influenced and continues to influence the nature of community. Scholars who follow

1 Pseudonym. 
this model believe that "industrialization and attendant urbanization have caused fundamental and irreversible changes in the nature of human relationships and community organization" [55] (p. 169). In this sense, the linear progress of modernity has resulted in the formation of large urban cities where meaningful attachment to community decreased [3-7,56-58]. As modernization assumed control of neighborhood and community development, individuals within urban contexts became detached and any sense of community was "secular and instrumental" [55] (p. 169).

Conversely, the systemic model in the work of Park and Burgess $[59,60]$ and Thomas [61] maintains that the development of urban cities does not inevitably result in a loss of community. Instead of size and density, city social structures allow individuals to experience greater solidarity [55]. Most importantly, the systemic model states that length of residency and population age have the greatest effect on community attachment [43] (p. 181) — the longer one lives in a particular area, the greater the sense of community he or she feels. Recent research embraces this systemic model within rural settings [62,63], and scholars also use the systemic model within the urban context, especially regarding neighborhoods within larger cities $[64,65]$. However, this research can apply the systemic model in an analysis of neighborhood effects in urbanizing areas. By finding evidence of neighborhood effects within urbanizing communities and by discerning the commonalities of residents in each neighborhood, we will show, using data from Creekdale, that community size and density are not the key factors in neighborhood development, but rather that neighborhoods can be characterized by length of residency. Creekdale, a traditional, rural, agricultural town, has been home to many families for generations. However, more recently, it has also become a bedroom community as new development attracts young families.

\subsection{Neighborhood Effects}

Location, city streets, census blocks, and density cannot be the only defining factors of a neighborhood - as in the past [66] — unless density is combined with significant social characteristics shared by the people within the neighborhoods [6]. Park claims that in "the course of time, every section and quarter of the city takes on something of the character and qualities of the inhabitants. Each separate part of the city is inevitably stained with the peculiar sentiments of the population" [1] (p. 579). Thus, as neighborhoods age, they are defined by their history and residents.

A number of effects, particularly social characteristics, tend to be grouped together at the neighborhood level [67]. Two crucial social characteristics, an individual's attachment to and satisfaction with their community, can help us understand aggregate neighborhood phenomena as well. Attachment and satisfaction have been studied in neighborhoods in urban blocks [68], as well as among individuals about their neighborhoods, but without comparing neighborhoods against each other $[69,70]$. One study found that residents who reported greater attachment to their neighborhood also were able to respond to disorder better, as well as feel higher stability [71]. More stable neighborhoods are considered more sustainable, in that people who live in more stable neighborhoods are assumed to care more about their community. Living in more stable neighborhoods also was associated with respondents feeling less vulnerable to crime [71]. Another study examined the level of attachment by neighborhood types and found that rural migrants in low-income neighborhoods are less attached compared to high-income neighborhoods and urban-born residents [72]. Lewicka [73] compares attachment levels in neighborhoods in four different cities and found that differences in means were statistically significant for attachment. This study compares the relationships between different types of places - apartment, neighborhood, city district, and city —and level of place attachment [73]. Regarding developing or restoring neighborhoods, measuring place attachment can help practitioners create better-informed projects. Long-time residents who have more intense attachment can help revitalization efforts in neighborhoods [74]. These findings show that neighborhood effects and attachment and satisfaction have unprecedented influence in multiple aspects of each individual's life.

While, as is noted by Kauppien [75] (p. 422), "reserch on neighborhood effects has been dominated by American Studies," researchers have also examined neighborhood effects in international settings. 
In Japan, for example, researchers found that health problems varied by neighborhood. One study showed that risk of stroke varies by level of neighborhood deprivation [76]. Another study found neighborhood effects to be correlated with the likelihood of elderly Japanese individuals being homebound [77], and one found that that cardiovascular disease risk varied by neighborhood characteristics [78]. In Australia, researchers found that neighborhood socioeconomic well-being was positively correlated with individual satisfaction [79]. Additionally, city planning researchers in Australia found that, while most residents of high-density neighborhoods were highly satisfied with their neighborhood and dwelling, those who reported better living conditions depending on their location, place of residence design, and amenities were more satisfied than those in other neighborhoods [80]. Child development researchers in Canada found that 4- and 5-year-old children's verbal ability scores were higher in affluent neighborhoods compared to children in poor neighborhoods, even after controlling for household socioeconomic status variables [81]. Additional child development research in Canada showed that childhood obesity varied by neighborhood characteristics [82]. A study that took place in the United Kingdom found that ethnic minorities have lower life satisfaction than majority populations; however, some minorities (Black, Indian, and Pakistani) who live in neighborhoods with a higher concentration of residents of their same ethnicity have higher life satisfaction [83]. Researchers reviewing literature studying neighborhood effects in Helsinki, Finland, found that, while family background explained whether or not a child would finish school, the type of education that young people sought was explained by neighborhood [75].

\subsection{The Urban Context}

Neighborhoods within cities are defined by the commonalities and solidary features shared among the residents of a particular geographic area [27,29]. A group of people bound together in this way creates the type of community they want to live in and secures the primary ties within them [84] (p. 5). In large urban areas, neighborhoods are divided along such lines, especially when numerous enclaves or "racial colonies" [1] (p. 582) develop a social organization according to race and social class. For instance, ethnic enclaves such as Chinatowns, Little Tokyos, and Little Armenias are considered as neighborhoods because of the ethnic composition of the residents, business owners, and patrons in each respective geographic area. Chinese, Japanese, and Armenians living in America choose to build ethnic enclaves as a way of accessing familiar cultural resources [85-90]. Wellman [42] explains this type of phenomenon as a part of the so-called "community saved" argument, in which people will always organize into communities no matter what the ecological, demographic, or social circumstances, seeking and creating primary ties by finding others who suit their wants and needs and by incorporating them into their community. Surrounding themselves with like-minded people helps to create a strong community. Thus, neighborhoods develop a homogenous character, generating the same primary ties via similarities in interest, background, and status. These characteristics, however, have disappeared in the purported "community lost" argument, which is largely focused on the removal of social interactions from the context of strong bonds and local solidarities to an impersonal context $[1,5,16,17,42]$. As urban areas grow, urban planners should prioritize neighborhood integration and the well-being of vulnerable populations [91] as well as preserve historical areas in order to secure sustainable development.

Primary ties are still important for the development of neighborhoods and communities as part of the community liberated paradigm, although most ties "now tend to form sparsely knit, spatially dispersed, ramifying structures instead of being bound up within a single densely knit solidarity" [42] (p. 1207). However, geography still plays a role in the development of community, because humans gather in physical places with others who share similar characteristics [92,93]. If community is defined by how a person experiences the world in a specific context of place and time [94,95], then each individual's experience of community is colored by their neighborhood. Members of a community will share similar, characteristically determined demographics with those who live near and associate with them [92,93]. 


\subsection{The Rural Context}

Despite its large rural population, most research in the United States on rural communities relies on demographic comparisons with limited generalizability or large-scale surveys that treat the "rural" community as a monolithic entity to be contrasted with metropolitan and urban communities [96-103]. Neighborhood effects have been studied and found within the urban context [53,67], but the research and analyses of their presence within rural communities are inadequate [42]. Even after extensive research on rural communities and rural community life, neighborhood effects have yet to be analyzed at rural and urbanizing levels. The neighborhood effects on a small scale validate the systemic model of community attachment, as rural towns do not have the size or density to drive the development of social processes that emerge when distinct neighborhoods form. Urban research on neighborhoods following the linear development model claims that neighborhood processes develop out of a human need to create and find social ties while living in a vast sea of people in dense, populous cities [6,55]. The fact that distinct neighborhoods develop in smaller towns [100] solicits a reevaluation of neighborhoods in urbanizing towns through the systemic model.

Most existing research on neighborhood effects takes place in urban cities where neighborhoods exist along census blocks and other geographic planes [6,53,54]. Neighborhood effects, however, are not only present and apparent in large cities or metropolitan areas; they can exist in any community, regardless of location, geographic area, or population size. Although there is limited research on the development of distinct neighborhoods within rural communities and urbanizing towns, similar sustainable development patterns [100] suggest that rural areas may experience comparable neighborhood effects as neighborhoods found within large cities [101]. Creekdale, an urbanizing town with a population of 26,349, has such neighborhoods.

\subsection{Urbanizing Context}

Rural planning and planning authorities have a significant impact on the development and spatial placement of economic activities [100]. The effectiveness of community planning influences outcomes including economic diversification, attracting human capital, meeting residents' needs, and long-term sustainability [100].

While urbanizing is not always a positive improvement for everyone in a community, as places urbanize and, in some cases, gentrify, minority groups experience poorer health [102], and those in periphery neighborhoods have lower income levels [103]. Rural areas in the process of urbanizing put those living in areas with concentrated poverty at risk [104], making the well-being and improvement of poverty-stricken areas an imperative part of sustainable development [91]. Feelings of attachment also vary with influxes of newcomers to the area; long-time residents who live in older neighborhoods feel more attached to the community [105] compared to neighborhoods made up of newcomers, who feel less attached [106]. At the heart of the urbanization of rural towns is a desire to preserve rural values and use them to raise the quality of rural life [100]. Neighborhood formation and selection, therefore, significantly influence the success of a rural town's urbanization and sustainable development [100].

\subsection{Summary and Expectations}

This case study shows that urbanizing communities experience neighborhood effects similar to those in urban towns. Using the systemic model, our study expands on previous literature by exploring how the length of residence rather than size and population density impacts neighborhood effects. Additionally, community attachment and satisfaction characteristics influence neighborhood effects, which should be considered in community planning processes and sustainable development initiatives. 


\section{Materials and Methods}

\subsection{Data}

To examine the creation of a community in an urbanizing setting, we use a historical case-study approach. Specifically, we used the Creekdale community because of the availability of detailed community data, its urbanizing town classification, and because the community has experienced a relatively steady rate of population growth. Furthermore, these data capture the community creation experience associated with population growth. Also, these data were temporally gathered-in 2009-while Creekdale was still small and urbanizing with relatively close community associations and ties. That is to say, although historically a rural town, when these data were collected, Creekdale was neither rural nor urban nor suburban, giving us access to a unique look into sustainable community development. Data for this study came from the 2009 Creekdale Citizens Viewpoint Survey (CCVS), an anonymous mail survey administered to a random sample of residents. All eligible addresses were extracted from Creekdale electric utility lists. There was limited coverage error because a few apartment units within Creekdale are not metered. Dillman's five-wave, multiple mailing sequence was used to collect the data [107]. The response rate was 58 percent, with 1006 completed surveys from a 1733-household sample.

\subsection{Measures}

To determine whether neighborhood effects exist in Creekdale, we looked at attitude, belief, behavior, and demographic survey questions and how they differ by neighborhood. Insofar as the CCVS is an anonymous survey, identifying respondents' neighborhoods was accomplished via a two-step process. First, we used a question within the CCVS, which asks each respondent to mark an $X$ indicating where they live on a map of the town. Second, a member of our research team, who has worked/lived in this community for $30+$ years, in consultation with city officials, identified natural road divisions and growth patterns in Creekdale. This detailed information regarding Creekdale facilitated the delineation of 11 neighborhoods, our independent and explanatory variables. A description of the 11 neighborhoods analyzed in the data follows (See Figure 1):

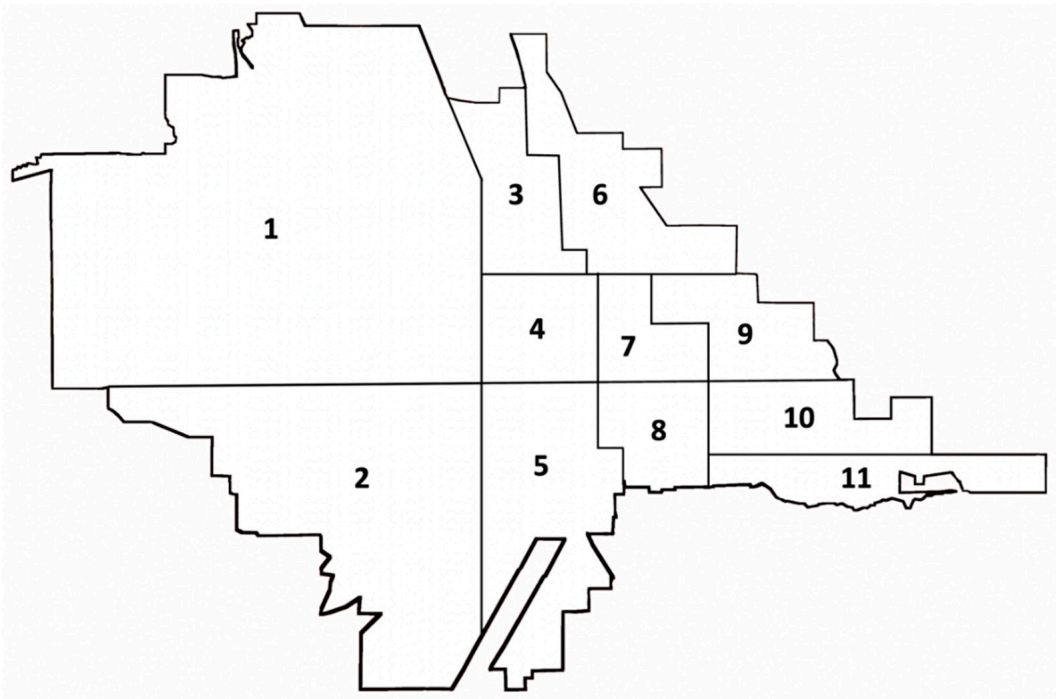

Figure 1. Creekdale Neighborhoods.

Neighborhood 1: locally known as "The West Fields," this neighborhood did not exist until about five years prior to the CCVS when farms were sold for development projects. Now this neighborhood is comprised of multiple retirement communities and single-family homes. 
Neighborhood 2: This neighborhood used to be farmland until the recent development of townhomes and apartment buildings.

Neighborhood 3: This neighborhood grew out of "Plat A" (Neighborhood 4) and became the business district.

Neighborhood 4: Known by residents as "Plat A," this neighborhood is comprised of the original downtown. "Plat A" has clear street boundaries on each side (400 W, $400 \mathrm{~N}, 400 \mathrm{E}$, and $400 \mathrm{~S}$ ) and all surrounding neighborhoods grew from this neighborhood.

Neighborhoods 5 and 8: These neighborhoods grew south out of "Plat A."

Neighborhoods 6 and 9: These neighborhoods grew up the mountain east of "Plat A." Neighborhood 6 is the "inexpensive" new housing, while Neighborhood 9 is the "old" new housing.

Neighborhood 7: This neighborhood is one of the first neighborhoods that formed (along with Neighborhood 3) once "Plat A" began to grow and spread.

Neighborhoods 10 and 11: These neighborhoods are the newest sections in Creekdale; the "expensive" new neighborhoods composed primarily of high-income, upper-middle-class residents.

We use various measures to tap different aspects of community experience. Specifically, we used principal component factor analysis with varimax rotation to reduce seven target predictor variables—suggested by previous studies e.g., [108-111]— to two independent dimensions representing community attachment and community satisfaction. In terms of community attachment, two survey questions- "How well do you feel you fit into your community?" and "How much do you have in common with most people in your neighborhood?"-load positively in a factor that accounts for $43.24 \%$ of variance shown among variables in the model. The remaining five survey questions-"How would you rate your community as a place to live?", "Taking all things together, how would you say things are these days?", "How satisfied are you with living in your community?", "Where would you rank your present community compared to your ideal community?", and "Which of the following statements best describes how well you like living in your present community?"-loaded positively on the community satisfaction factor and account for $66.11 \%$ of variance shown among variables in the model. All seven survey questions were measured on a scale of $1-5$, with higher numbers denoting more positive sentiments.

To further paint a picture of the composition of the neighborhoods included in our study, we included various household and demographic variables suggested by the above-referenced literature. Household attributes were captured through a number of variables. First, Income measures, using ordinal response categories, the previous year's total household income (in US dollars). Additionally, we included a dummy variable denoting whether a household is internet-equipped (yes $=1$ ). Likewise, a series of dummy variables were included for Homeownership (own =1), non-English speaking household $($ no $=1)$, household type (single-family $=1)$. Additionally, we included a measure of household size indicating the number of people who currently live in the respondent's home, which we truncated at $6+$.

With regards to demographic variables, we included birthplace, measured with the following categorical response options: Creekdale county, [anonymized US] state, Other US state, and Other country. Likewise, we measured Place of Employment with a series of categorical response options: Creekdale, [anonymized county seat], [anonymized neighboring town to the south], [anonymized neighboring town to the north], and other location. Additionally, we included a dummy variable to measure if the respondent telecommutes for work (yes =1). Respondents' education level and age were both measured as continuous-level variables. Lastly, dummy variables were included for marital status ( married or widowed $=1)$, race $($ white $=1)$, and biological sex $($ female $=1)$. Descriptive statistics for all variables used in our models are displayed in Table 1. 
Table 1. Descriptive Statistics.

\begin{tabular}{|c|c|c|c|c|}
\hline Independent Variable & Mean/Percent & SD & Min & Max \\
\hline \multicolumn{5}{|l|}{ Neighborhood } \\
\hline Neighborhood 1 & $4.96 \%$ & & & \\
\hline Neighborhood 2 & $7.08 \%$ & & & \\
\hline Neighborhood 3 & $5.08 \%$ & & & \\
\hline Neighborhood 4 & $14.52 \%$ & & & \\
\hline Neighborhood 5 & $12.16 \%$ & & & \\
\hline Neighborhood 6 & $9.45 \%$ & & & \\
\hline Neighborhood 7 & $10.15 \%$ & & & \\
\hline Neighborhood 8 & $12.16 \%$ & & & \\
\hline Neighborhood 9 & $7.79 \%$ & & & \\
\hline Neighborhood 10 & $8.38 \%$ & & & \\
\hline Neighborhood 11 & $8.26 \%$ & & & \\
\hline Community Attachment & 0.00 & 0.75 & -2.55 & 2.11 \\
\hline Community Satisfaction & 0.00 & 0.83 & -3.48 & 1.98 \\
\hline \multicolumn{5}{|l|}{ Household attributes } \\
\hline Less than $\$ 15,000$ & $4.94 \%$ & & & \\
\hline$\$ 15,000-\$ 34,000$ & $17.22 \%$ & & & \\
\hline$\$ 35,000-\$ 49,000$ & $20.52 \%$ & & & \\
\hline$\$ 50,000-\$ 74,000$ & $26.30 \%$ & & & \\
\hline$\$ 75,000-\$ 99,000$ & $15.21 \%$ & & & \\
\hline$\$ 100,000+$ & $16.04 \%$ & & & \\
\hline \multicolumn{5}{|l|}{ Internet-equipped } \\
\hline Yes & $87.43 \%$ & & & \\
\hline \multicolumn{5}{|l|}{ Homeownership } \\
\hline Own & $87.12 \%$ & & & \\
\hline \multicolumn{5}{|l|}{ Non-English at home } \\
\hline No & $92.41 \%$ & & & \\
\hline \multicolumn{5}{|l|}{ Household Type } \\
\hline Single family & $83.72 \%$ & & & \\
\hline Household Size & 3.47 & 1.82 & 1 & 11 \\
\hline \multicolumn{5}{|l|}{ Respondent attributes } \\
\hline \multicolumn{5}{|l|}{ Birthplace } \\
\hline Anonymous county & $36.31 \%$ & & & \\
\hline Anonymous US state & $24.28 \%$ & & & \\
\hline Other US state & $34.55 \%$ & & & \\
\hline Other country & $4.86 \%$ & & & \\
\hline \multicolumn{5}{|l|}{ Employment: Place } \\
\hline Creekdale & $26.50 \%$ & & & \\
\hline North of Creekdale & $45.86 \%$ & & & \\
\hline South of Creekdale & $27.07 \%$ & & & \\
\hline Other & $0.56 \%$ & & & \\
\hline \multicolumn{5}{|l|}{ Employment: Telecommute } \\
\hline Yes & $20.04 \%$ & & & \\
\hline Education level & 14.77 & 2.43 & 11 & 22 \\
\hline Age & 58.70 & 17.46 & 12 & 88 \\
\hline \multicolumn{5}{|l|}{ Marital Status } \\
\hline Married & $88.85 \%$ & & & \\
\hline Race & & & & \\
\hline White & $94.30 \%$ & & & \\
\hline Sex & & & & \\
\hline Female & $54.80 \%$ & & & \\
\hline
\end{tabular}

\subsection{Analytic Strategy}

The fundamental empirical task for this study was to identify, if they exist, neighborhood effects in a small, urbanizing rural community. To determine the existence of neighborhood effects, we relied 
on a factor structure that best represents the data. Because we have multiple survey questions that provide data about attachment and satisfaction, we used factor analysis to create variables for community attachment and community satisfaction. We then tested for significant variance between neighborhoods. To do so, we used ANOVA statistics followed by the Bonferroni post hoc test to analyze the differences between neighborhoods in the factor scores. An additional spatial analysis of the ANOVA and Bonferroni results was then produced. This spatial analysis illustrates detailed neighborhood changes and provides a more robust analysis of Creekdale. ANOVA statistics have been used in studies to explore community attachment and involvement [112], to compare attachment and satisfaction for rural nurses [113], to examine the relationship between housing types and community attachment [73]. Analysis of variance between groups is an appropriate test for our study, as we are looking at the variance in attachment and satisfaction by neighborhood.

\section{Results}

Table 2 presents the ANOVA statistics testing for the presence of neighborhood effects by attachment and satisfaction. For both community attachment and satisfaction, the results of the F-test are noteworthy, indicating significant between-neighborhood variance. We found the following variables reflecting residents' attitudes, beliefs, and behaviors to have a significant F-test at the $p<0.05$ level: attachment (feelings that one fits and has common interests with others in the community), satisfaction (overall satisfaction with different aspects of life in Creekdale). The post hoc tests, however, were not significant for many of the variables, indicating that the difference in means was not meaningfully different between any two neighborhoods. Part of this can be attributed to the strictness of the Scheffe post hoc test. However, a significant F-test provides evidence of neighborhood effects in Creekdale, even without the support of significant post hoc tests.

Table 2. Presence of Neighborhood Effects by Attachment and Satisfaction.

\begin{tabular}{cccc}
\hline Variable & F-Test & $p$-Value for F-Test & Intraclass Correlation \\
\hline $\begin{array}{c}\text { Community Attachment } \\
\text { Attachment }\end{array}$ & 2.29 & $0.012 *$ & 0.01706 \\
$\begin{array}{c}\text { Community Satisfaction } \\
\text { Satisfaction }\end{array}$ & 3.49 & $0.000 *$ & 0.03243 \\
\hline
\end{tabular}

${ }^{*}$ Indicates a statistically significant $p$-value $(p<0.05)$.

Additional post hoc testing indicated that, although the overall changes in community attachment and satisfaction were significant, they were not spatially even across all eleven neighborhoods. Therefore, to further understand neighborhood effects, we mapped the mean neighborhood factor scores for community attachment and satisfaction and examined the results for spatial patterns. Figure 2 shows the spatial distribution of the mean community attachment score, while Figure 3 reveals the spatial patterns of mean community satisfaction by neighborhood in Creekdale. In both cases, there is a clustering of higher scores in the newer eastern neighborhoods, while the less-defined western neighborhoods reported negative scores. A post hoc Bonferroni test shows that, even though there is a clear spatial pattern to the distribution of mean neighborhood scores, most between-neighborhood differences were not significant. The only statistically significant comparison between neighborhoods was at the extreme ends of the distribution, i.e., Neighborhood 2 vs. Neighborhood 11. Additional analysis comparing the mean eastern neighborhoods to mean western neighborhood scores was significant. The significant difference in the means between eastern and western neighborhoods provides further evidence that the neighborhood, even in an urbanizing community, shapes the lived community experience. Additional analysis and mapping of factors examined in Table 3 show similar spatial distributions. 


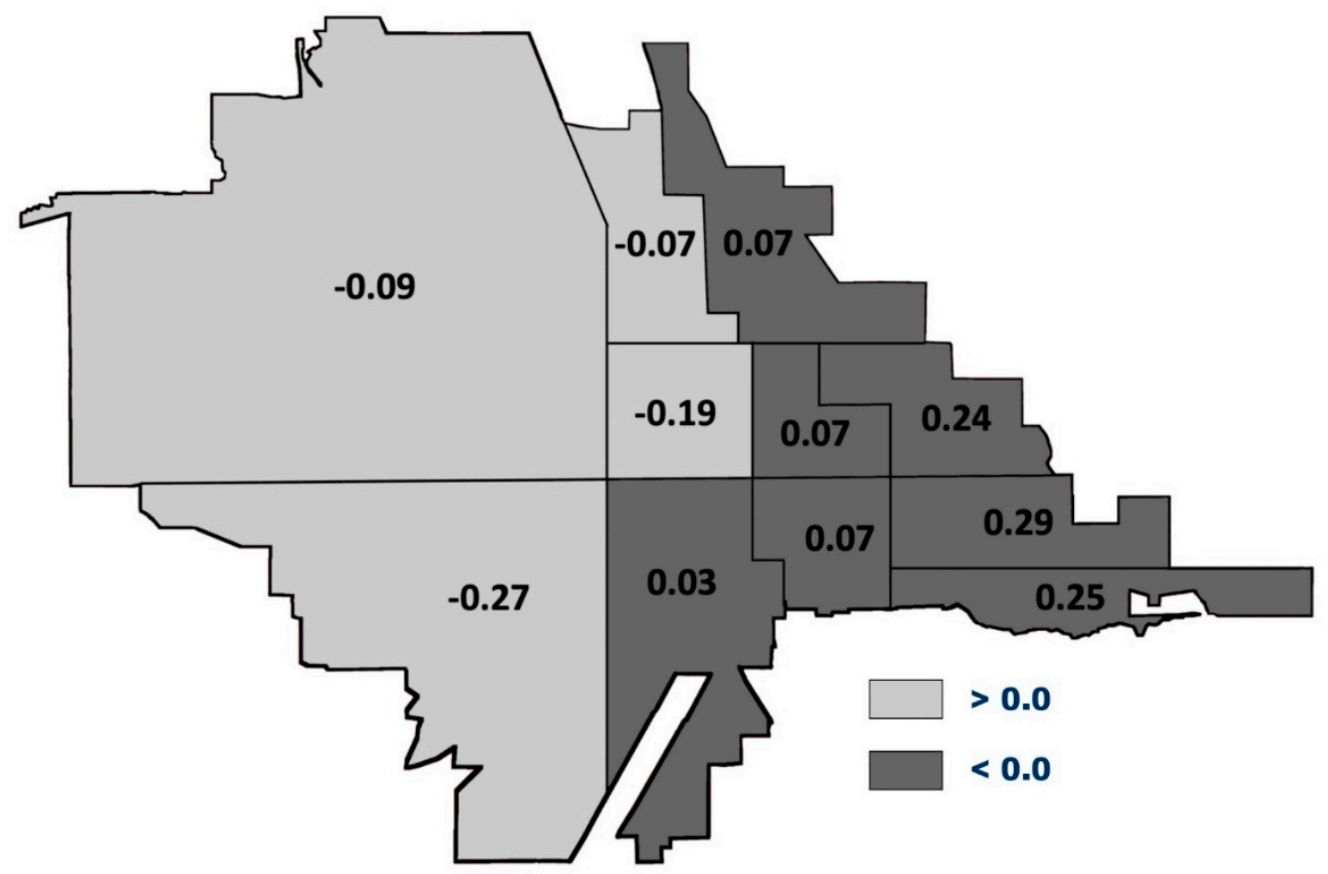

Figure 2. Spatial Distribution of Mean Community Attachment Score by Neighborhood.

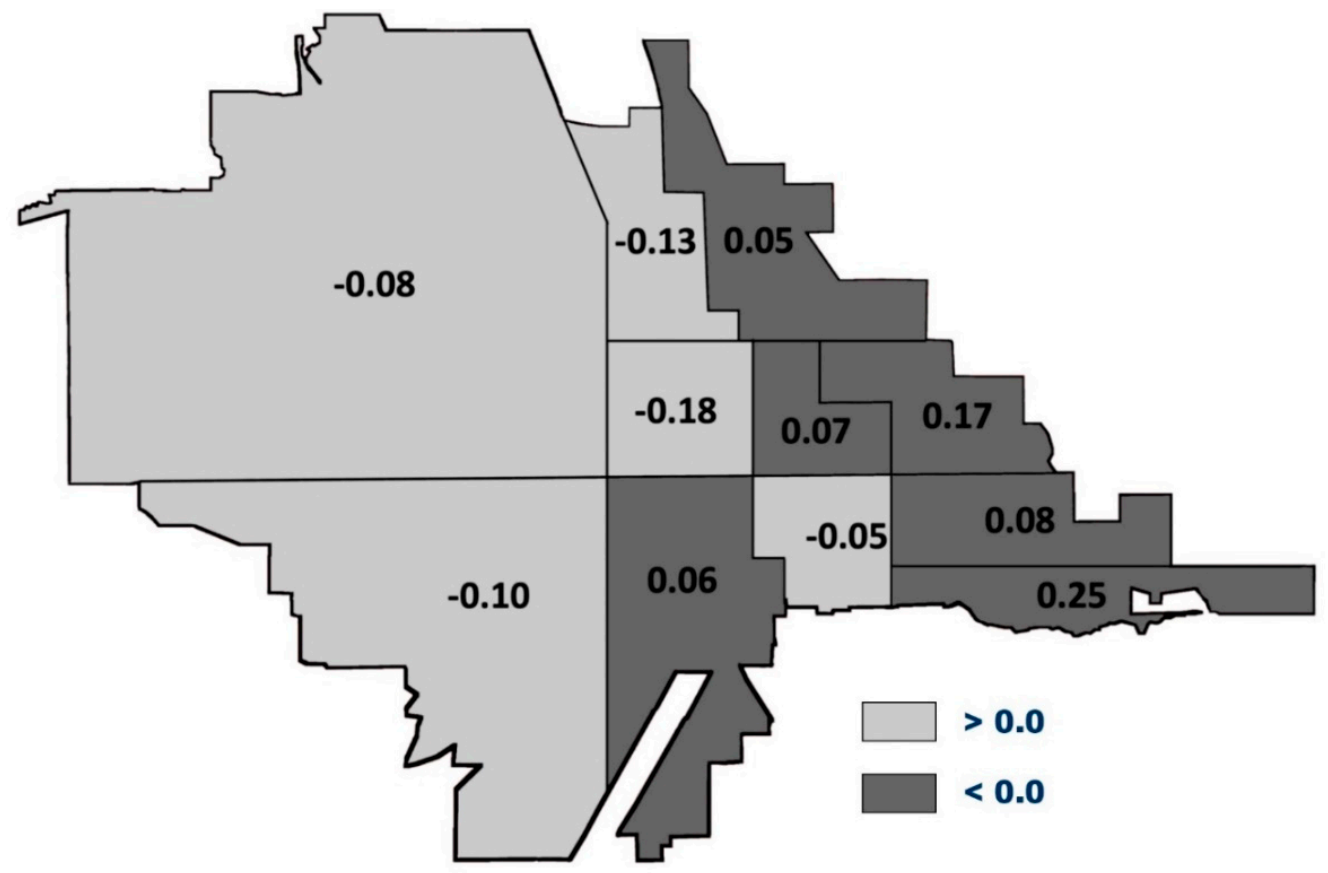

Figure 3. Spatial Distribution of Mean Community Satisfaction Score by Neighborhood.

Along with these attachment and satisfaction neighborhood effects, we found demographic neighborhood effects in our data (see Table 3 ). The following demographics are significant at the $p<0.05$ level: income, internet equipped, homeownership, household size, house type (e.g., single-family home, apartment, etc.), age, birthplace, education level, marital status, race, and sex. These demographic characteristics differ distinctly by neighborhood, indicating, again, that neighborhood effects exist in small towns and large cities. 
Table 3. Demographic Data (Dependent Variable = neighborhoods).

\begin{tabular}{|c|c|c|c|c|}
\hline Independent Variable & Chi-Square Test & F-Test ${ }^{\dagger}$ & $p$-Value & ICC * \\
\hline \multicolumn{5}{|l|}{ Household attributes } \\
\hline Income & 164.4902 & & $0.000 *$ & \\
\hline Internet-equipped & 19.2583 & & $0.037^{*}$ & \\
\hline Homeownership & 47.1446 & & $0.000 *$ & \\
\hline Non-English at home & 15.0993 & & 0.128 & \\
\hline Household Size & & 11.53 & $0.000 *$ & 0.12767 \\
\hline Household Type & 88.6000 & & $0.000 *$ & \\
\hline \multicolumn{5}{|l|}{ Respondent attributes } \\
\hline Age & & 6.20 & $0.000 *$ & 0.06503 \\
\hline Birthplace & 50.4287 & & 0.011 * & \\
\hline Education level & & 4.23 & $0.000 *$ & 0.04096 \\
\hline Employment: Place & 34.0697 & & 0.278 & \\
\hline Employment: Telecommute & 9.6544 & & 0.471 & \\
\hline Marital Status & 20.6812 & & $0.023 *$ & \\
\hline Race & 33.8423 & & $0.000 *$ & \\
\hline Sex & 20.0731 & & $0.029 *$ & \\
\hline
\end{tabular}

${ }^{*}$ Indicates a statistically significant $p$-value $(p<0.05) .{ }^{+}$F-test and Intraclass Correlation (ICC) are used with continuous variables.

\section{Discussion}

This case study applied neighborhood and community theory to data from a community survey of the urbanizing town of Creekdale and contributes to current research in two ways. First, previous research on both neighborhood effects and community tends to focus on urban rather than rural life [1-8]. However, the focus of this study was on neighborhood effects and community within an urbanizing area. The presence of neighborhood effects regarding the attitudes, beliefs, behaviors, and demographics at varying spatial levels in Creekdale provides empirical evidence that the development of the community by neighborhoods is not just an urban phenomenon. Neighborhood can influence communities during a rural-to-urban transition.

The second contribution of this study is that the results provide empirical support for the application of the systemic model of community attachment in a rural and urbanizing context [38]. Many studies have analyzed rural communities as a whole [97,99], but this analysis of distinct neighborhoods within a rural-to-urbanizing town provides much-needed data regarding the manifestation of the systemic model of community attachment. As rural communities are much smaller in population and density than urban areas, studies following the assumptions of the linear development model [38] have not been concerned with analyzing the neighborhood effects in smaller urbanizing towns [63]. Despite research that shifts community studies away from the Wirthian tradition and the linear development model, community is still analyzed primarily in the urban context, which intentionally or unintentionally perpetuates the idea that communities with small populations are homogenous [38,43]. Insofar as, methodologically, most research pertaining to neighborhood effects delineate neighborhoods via census blocks and other geographic planes $[6,53,54]$, this study extends the research into rural and urbanizing areas where there are less distinct methods for defining a neighborhood and, thereby, provides a framework for future analysis in other rural and urbanizing towns.

With the presence of neighborhood effects identified in Creekdale, the idea that there may be no difference in the way urban and urbanizing neighborhoods from within larger communities is validated and warrants further research. Since we found evidence of neighborhoods in small towns that are characterized by stronger social ties and less diversity in the population [35], industrialization and urbanization are not likely to be the reasons that neighborhoods exist. Individualization is emerging as a dominant characteristic within communities across the general population, and the impetus behind neighborhood selection is no longer about creating a group or community as a whole. Instead, individuals are attempting to find a place that suits their wants and needs. With more individualistic 
motives for establishing a community in neighborhoods in a more "liquid" world, the presence of neighborhoods is not simply the product of population size or proximity to others. Still, more studies are needed to find a definite source of neighborhood development.

As a case study, the results from Creekdale are limited to the population of that town and cannot be generalized to other rural or urbanizing areas. We believe, however, that this study can be replicated in other rural and urbanizing communities, and the results will be consistent with those presented here. This study provides a robust framework for future surveys and studies to follow to study the presence of neighborhood effects in other rural and urbanizing towns. Other communities can model the Creekdale surveys, including the use of a geographic "Neighborhoods" variable by asking the participants to identify the general location in which they live. Further research, as well, on Creekdale should continue to measure different neighborhood effects over time, and other small urbanizing rural towns can follow our framework to apply similar analyses to other places. If other towns have the same results as Creekdale, the standard for measuring community in neighborhoods and for using the systemic model must be changed. This research has the potential to alter our understanding of the modern experience of community in rural, urbanizing, and urban contexts. With it, we can understand the factual motivations and characteristics behind the development of neighborhoods.

\section{Conclusions}

Given our findings of the presence of neighborhood effects in an urbanizing community, this study lays the groundwork for research in other rural and urbanizing communities. The implications of our findings are significant. If we are correct in assuming that neighborhood effects are present within all communities, regardless of size, then the fact that distinct neighborhoods develop in smaller towns solicits a reevaluation of the concept of the neighborhood through the systemic model. Industrialization and urbanization are not the reasons large neighborhoods exist. As individualization emerges as a dominant characteristic within communities across the population, the impetus behind neighborhood selection is no longer about creating a group or community as a whole, but rather is a function of individuals attempting to find a place that suits their particular wants and needs. Our data show that neighborhoods can and do exist in places with less density and a smaller population, but data are needed from additional small rural communities to validate the idea that a characteristic of neighborhoods is individualism. Future studies can also shed light on other social trends that may exist in determining rural neighborhood selection and neighborhood selection in general.

This research proposes that there is no significant difference between the way urban, urbanizing, and rural neighborhoods form within their larger communities. If studies of other rural communities find similar results to this Creekdale study, then there must be a reevaluation of urban neighborhoods. If neighborhoods consistently exist within rural and small towns, there is a need to understand why they also exist in urban areas. This will further our understanding of and research into neighborhoods in general, rather than sustain a dichotomous view of neighborhoods in urban areas or neighborhoods in rural areas alone. If other towns yield the same results as this study, the standard for measuring community in neighborhoods and for using the systemic model must be changed to accommodate these findings. This area of research has the potential to alter our understanding of the modern experience of community both in rural and urban contexts. With it, researchers can gain a deeper understanding of the true motivations and characteristics behind the development of neighborhoods. Indeed, identifying the similarities and differences between urban and rural neighborhoods is critical to understanding neighborhoods and communities in general.

It is essential that we recognize that the development of community through neighborhoods is not only an urban phenomenon. Neighborhoods also develop in small and rural towns. Communities once viewed as constituting a collective body are now characterized by individualism [45]. This trend is represented in our findings and shows that the increasing individuality that has swept large urban cities is also present in small rural communities, allowing neighborhood effects to manifest themselves in the smaller sections (i.e., neighborhoods) of rural towns. This supports the view that the systemic 
model of community attachment holds true in rural areas. In terms of community, size does not matter and neighborhood effects exist in an urbanizing context.

Author Contributions: Conceptualization, M.R.C. and R.B.B.; Data curation, M.R.C. and R.B.B.; Formal analysis, M.R.C., J.E.J. and S.R.S.; Funding acquisition, M.R.C.; Supervision, M.R.C.; Writing—original draft, M.R.C., T.M. and R.B.B.; Writing-review \& editing, M.R.C., J.E.J., S.R.S. and L.D.E. All authors have read and agree to the published version of the manuscript.

Funding: This research was funded in part by a Brigham Young University Mentoring Environment Grant.

Acknowledgments: The authors would thank Tisah Quarnberg, Leila Nielsen, Jeremy Flaherty, and the members of Ralph Brown's SOC 528 course for their contributions and comments on an earlier draft of the paper.

Conflicts of Interest: The authors declare no conflict of interest.

\section{References}

1. Park, R.E. The City: Suggestions for the Investigation of Behavior in the city Environment. Am. J. Sociol. 1915, 20, 579-583. [CrossRef]

2. Wirth, L. The Ghetto; The University of Chicago Press: Chicago, IL, USA, 1928; pp. 1-306.

3. Shaw, C.R. Delinquency Areas; The University of Chicago Press: Chicago, IL, USA, 1929; pp. 1-394.

4. Zorbaugh, H.W. The Gold Coast and the Slum: A Sociological Study of Chicago's Near North Side; The University of Chicago Press: Chicago, IL, USA, 1929; pp. 1-287.

5. Cressey, P.G. The Taxi-Dance Hall; The University of Chicago Press: Chicago, IL, USA, 1932; pp. 1-300.

6. Wirth, L. Urbanism as a Way of Life. Am. J. Sociol. 1938, 44, 1-24. [CrossRef]

7. Faris, R.E.L.; Dunham, H.W. Mental Disorder in Urban Areas; The University of Chicago Press: Chicago, IL, USA, 1939; pp. 1-270.

8. Gottdiener, M.; Budd, L. Key Concepts in Urban Studies; Sage: Thousand Oaks, CA, USA, 2005; pp. 1-188.

9. Bender, T. Community and Social Change in America; Rutgers University Press: New Brunswick, NJ, USA, 1978; pp. 1-159.

10. Hauser, P.M. The Study of Urbanization; John Wiley \& Sons: New York, NY, USA, 1965; pp. 1-554.

11. Fischer, C. Toward a Subcultural Theory of Urbanism. Am. J. Sociol. 1975, 80, 1319-1341. [CrossRef]

12. Warren, R.L. The Community in America; Rand McNally: Chicago, IL, USA, 1972; pp. 1-418.

13. Calhoun, J.B. Population density and social pathology. Sci. Am. 1962, 206, 139-148. [PubMed]

14. Hall, E.T. The Hidden Dimension; Random House Inc: New York, NY, USA, 1966; pp. 1-201.

15. Tucker, J.; Friedman, S.T. Population Density and Group Size. Am. J. Sociol. 1972, 77, 742-749. [CrossRef] [PubMed]

16. Woodsworth, J.S. My Neighbor; University of Toronto Press: Toronto, ON, Canada, 1911; pp. 1-341.

17. Nisbet, R.A. The Quest for Community; Oxford University Press: London, UK, 1969; pp. 1-330.

18. Janowitz, M. The Community Press in an Urban Setting; The University of Chicago Press: Chicago, IL, USA, 1952; pp. 1-256.

19. Mumford, L. In the Name of Sanity; Harcourt, Brace: New York, NY, USA, 1954; pp. 1-244.

20. Young, M.; Willmott, P. Family and Kinship in East London; Penguin Books: Baltimore, MD, USA, 1957; pp. 1-221.

21. Jacobs, J. The Death and Life of Great American Cities; Random House: New York, NY, USA, 1961; pp. 1-458.

22. Gans, H.J. The Urban Villagers: Group and Class in the Life of Italian-Americans; The Free Press: New York, NY, USA, 1962; pp. 1-367.

23. Greer, S.A. The Emerging City: Myth and Reality; The Free Press: New York, NY, USA, 1962; pp. 1-232.

24. Liebow, E. Tally's Corner; Little, Brown: Boston, MA, USA, 1967; pp. 1-260.

25. Keller, S. The Urban Neighborhood: A Sociological Perspective; Random House: New York, NY, USA, 1968; pp. 1-201.

26. Suttles, G.D. The Social Construction of Communities; University of Chicago Press: Chicago, IL, USA, 1972; pp. 1-201.

27. Craven, P.; Wellman, B. The Network City. Sociol. Inq. 1973, 43, 57-88. [CrossRef]

28. Stack, C.B. All Our Kin; Harper \& Row: New York, NY, USA, 1974; pp. 1-175. 
29. Pickvance, C.G. Voluntary Associations and the Persistence of Multiple Ties; Mimeographed; University of Manchester, Department of Sociology: Manchester, UK, 1975.

30. Tilly, C. Do Communities Act? Sociol. Inq. 1973, 43, 209-240. [CrossRef]

31. Merton, R.K. Social Theory and Social Structure; The Free Press: New York, NY, USA, 1957; pp. 1-645.

32. Kadushin, C. The Friends and Supporters of Psychotherapy: On Social Circles in Urban Life. Am. Sociol. Rev. 1966, 31, 786-802. [CrossRef]

33. Shulman, N. Urban Social Networks. Ph.D. Thesis, University of Toronto, Toronto, ON, Canada, 1972.

34. Shulman, N. Network Analysis: A New Addition to an Old Bag of Tricks. Acta Sociol. 1976, 19, $307-323$. [CrossRef]

35. Granovetter, M.S. The Strength of Weak Ties. Am. J. Sociol. 1973, 78, 1360-1380. [CrossRef]

36. Laumann, E.O. Bonds of Pluralism: The Form and Substance Urban Social Networks; J. Wiley: New York, NY, USA, 1973; pp. 1-342.

37. Breiger, R.L. The Duality of Persons and Groups. Soc. Forces 1974, 53, 181-190. [CrossRef]

38. Kasarda, J.D.; Janowitz, M. Community Attachment in Mass Society. Am. Sociol. Rev. 1974, 39, 328-339. [CrossRef]

39. Shorter, E. The Making of the Modern Family; Basic Books: New York, NY, USA, 1977; pp. 1-368.

40. Fischer, C. The Urban Experience; Harcourt Brace Jovanovich: New York, NY, USA, 1976; pp. 1-309.

41. Walker, G. Social Networks and Territory in a Commuter Village, Bond Head, Ontario. Can. Geogr. 1977, 21, 329-350. [CrossRef]

42. Wellman, B. The Community Question: The Intimate Networks of East Yorkers. Am. J. Sociol. 1979, 84, 1201-1231. [CrossRef]

43. Goudy, W.J. Further Considerations of Indicators of Community Attachment. Soc. Indic. Res. 1982, 11, 181-192. [CrossRef]

44. Bauman, Z. Community: Seeking Safety in an Insecure World; Polity Press: Cambridge, MA, USA, 2001; pp. 1-159.

45. Bauman, Z. Liquid Life; Polity Press: Cambridge, MA, USA, 2005; pp. 1-164.

46. Bauman, Z. Liquid Times; Polity Press: Cambridge, MA, USA, 2007; pp. 1-70.

47. Crowder, K.; Pais, J.; South, S.J. Neighborhood diversity, metropolitan constraints, and household migration. Am. Sociol. Rev. 2012, 77, 325-353. [CrossRef]

48. Gabriel, R.; Spring, A. Neighborhood Diversity, Neighborhood Affluence: An Analysis of the Neighborhood Destination Choices of Mixed-Race Couples with Children. Demography 2019, 56, 1051-1073. [CrossRef]

49. McKnight, M.; Gibbs, B.; Sanders, S.S.; Cope, M.R.; Jackson, J.E. Distance and Place: The Relationship of Distance and Community Population Size to Community Satisfaction. Community Dev. 2019, 50, 389-405.

50. Colling, M.R.; Stovall, J.; Flaherty, J.; Cope, M.R.; Brown, R.B. From Mass Consumer Society to a Society of Consumers: Consumption and the Experience of Community in Late Modernity. Community Dev. 2017, 48, 460-482. [CrossRef]

51. Bauman, Z. Modernity and Ambivalence; Cornell University Press: Ithaca, NY, USA, 1991; pp. 1-285.

52. Marotta, V. Zygmunt Bauman: Order, Strangerhood, and Freedom. Thesis Elev. 2002, 70, 36-54. [CrossRef]

53. Sampson, R.J.; Bartusch, D.J. Legal Cynicism and (Subcultural?) Tolerance of Deviance: The Neighborhood Context of Racial Differences. Law Soc. Rev. 1998, 32, 777-804. [CrossRef]

54. Montgomery, M.R.; Hewett, P.C. Urban Poverty and Health in Developing Countries: Household and Neighborhood Effects. Demography 2005, 42, 397-425. [CrossRef] [PubMed]

55. Welch, R. Community Development and Metropolitan Religious Commitment: A Test of Two Competing Models. J. Sci. Study Relig. 1983, 22, 167-181. [CrossRef]

56. Tonnies, F. Community and Civil Society; Cambridge University Press: Cambridge, UK, USA, 2001; pp. 1-319.

57. Shaw, C.R. Brothers in Crime; The University of Chicago Press: Chicago, IL, USA, 1931.

58. Polanyi, K. The Great Transformation; Beacon Press: Boston, MA, USA, 1944; pp. 1-317.

59. Park, R.E.; Burgess, E. Introduction to the Science of Sociology; University of Chicago Press: Chicago, IL, USA, 1969; pp. 1-1040.

60. Park, R.E.; Burgess, E. The City; University of Chicago Press: Chicago, IL, USA, 2019.

61. Thomas, W.I. On Social Organization and Social Personality; University of Chicago Press: Chicago, IL, USA, 1967; pp. 1-311. 
62. Cope, M.R.; Currit, A.; Flaherty, J.; Brown, R.B. Making sense of community action and voluntary participation-A multilevel test of multilevel hypotheses: Do communities act? Rural Sociol. 2016, 81,3-34. [CrossRef]

63. Flaherty, J.; Brown, R. A Multilevel Systemic Model of Community Attachment: Assessing the Relative Importance of the Community and Individual Levels. Am. J. Sociol. 2010, 116, 503-542. [CrossRef]

64. Taylor, J.E.; Arango, J.; Hugo, G.; Kouaouci, A.; Massey, D.S.; Pellegrino, A. International Migration and Community Development. Popul. Index 1996, 62, 397-418. [CrossRef]

65. Hipp, J.R. A dynamic view of neighborhoods: The reciprocal relationship between crime and neighborhood structural characteristics. Soc. Probl. 2010, 57, 205-230. [CrossRef]

66. Guest, A.M.; Lee, B.A. How Urbanites Define their Neighborhoods. Popul. Environ. 1984, 7, 32-56. [CrossRef]

67. Sampson, R.J.; Morenoff, J.D.; Gannon-Rowley, T. Assessing Neighborhood Effects: Social Processes and New Directions in Research. Annu. Rev. Sociol. 2002, 28, 443-478. [CrossRef]

68. Ringel, N.B.; Finkelstein, J.C. Differentiating Neighborhood Satisfaction and Neighborhood Attachment Among Urban Residents. Basic Appl. Soc. Psychol. 1991, 12, 177-193. [CrossRef]

69. Grinstein-Weiss, M.; Yeo, Y.; Anacker, K.; Van Zandt, S.; Freeze, E.B.; Quercia, R.G. Homeownership and Neighborhood Satisfaction among Low- and Moderate-Income Households. J. Urban Aff. 2011, 33, $247-265$. [CrossRef]

70. O’Brien, D.J.; Ayidiya, S. Neighborhood Community and Life Satisfaction. Community Dev. 1991, 22, 21-37. [CrossRef]

71. Taylor, R. Neighborhood responses to disorder and local attachments: They Systemic Model of Attachment, Social Disorganization, and Neighborood Use Value. Sociol. Forum 1996, 11, 41-74. [CrossRef]

72. Wu, F. Neighborhood Attachment, Social Participation, and Willingness to Stay in China's Low-Income Communities. Urban Aff. Rev. 2012, 48, 547-570. [CrossRef]

73. Lewicka, M. What makes neighborhood different from home and city? Effects of place scale on place attachment. J. Environ. Psychol. 2010, 30, 35-51. [CrossRef]

74. Brown, B.; Perkins, D.D.; Brown, G. Place attachment in a revitalizing neighborhood: Individual and block levels of analysis. J. Environ. Psychol. 2003, 23, 259-271. [CrossRef]

75. Kauppinen, T.M. Neighborhood effects in a European city: Secondary education of young people in Helsinki. Soc. Sci. Res. 2007, 36, 421-444. [CrossRef]

76. Honjo, K.; Iso, H.; Nakaya, T.; Hanibuchi, T.; Ikeda, A.; Inoue, M.; Sawada, N.; Tsugane, S.; Japan Public Health Center-based Prospective Study Group. Impact of neighborhood socioeconomic conditions on the risk of stroke in Japan. J. Epidemiol. 2015, 25, 254-260. [CrossRef]

77. Murayama, H.; Yoshie, S.; Sugawara, I.; Wakui, T.; Arami, R. Contextual effect of neighborhood environment on homebound elderly in a Japanese community. Arch. Gerontol. Geriatr. 2012, 54, 67-71. [CrossRef]

78. Inoue, Y.; Stickley, A.; Yazawa, A.; Shirai, K.; Amemiya, A.; Kondo, N.; Kondo, K. Neighborhood characteristics and cardiovascular risk among older people in Japan: Findings from the JAGES project. PLoS ONE 2016, 11, e0164525. [CrossRef]

79. Shields, M.A.; Price, S.W.; Wooden, M. Life satisfaction and the economic and social characteristics of neighbourhoods. J. Popul. Econ. 2009, 22, 421-443. [CrossRef]

80. Buys, L.; Miller, E. Residential satisfaction in inner urban higher-density Brisbane, Australia: Role of dwelling design, neighbourhood and neighbours. J. Environ. Plan. Manag. 2012, 55, 319-338. [CrossRef]

81. Kohen, D.E.; Brooks-Gunn, J.; Leventhal, T.; Hertzman, C. Neighborhood income and physical and social disorder in Canada: Associations with young children's competencies. Child Dev. 2002, 73, 1844-1860. [CrossRef] [PubMed]

82. Veugelers, P.; Sithole, F.; Zhang, S.; Muhajarine, N. Neighborhood characteristics in relation to diet, physical activity and overweight of Canadian children. Int. J. Pediatric Obes. 2008, 3, 152-159. [CrossRef] [PubMed]

83. Knies, G.; Nandi, A.; Platt, L. Life satisfaction, ethnicity and neighbourhoods: Is there an effect of neighbourhood ethnic composition on life satisfaction? Soc. Sci. Res. 2016, 60, 110-124. [CrossRef]

84. Mumford, L. The City in History; Harcourt Inc: San Diego, CA, USA, 1961.

85. Waldinger, R. The Ethnic Enclave Debate Revisited. Int. J. Urban Reg. Res. 1993, 17, 444-452. [CrossRef]

86. Light, I.; Sabagh, G.; Bozorgmehr, M.; Der-Marttrosian, C. Beyond the Ethinc Enclave Economy. Soc. Probl. 1994, 41, 65-80. [CrossRef] 
87. Ong, A. Cultural Citizenship as Subject-Making: Immigrants Negotiate Racial and Cultural Boundaries in the United States. Curr. Anthropol. 1996, 37, 737-762. [CrossRef]

88. Flores, W.V.; Benmayor, R. Latino Cultural Citizenship: Claiming Identity, Space and Rights; Beacon Press: Boston, MA, USA, 1997; p. 1184.

89. Pakulski, J. Cultural Citizenship. Citizsh. Stud. 1997, 1, 73-86. [CrossRef]

90. Lin, J. Reconstructing Chinatown: Ethnic Enclave, Global Change; University of Minnesota Press: Minneapolis, MN, USA, 1998; pp. 1-272.

91. Koehler, K. Socially Sustainable Planning for Ursvik's Development and Integration. Kth R. Inst. Technol. 2018, 6-12.

92. Hillery, G.A. Definitions of Community: Areas of Agreement. Rural Sociol. 1955, 20, 111-123.

93. Leopold, A. A Sand County Almanac; Oxford University Press: London, UK, 1990; pp. 1-295.

94. Mealor, T.W., Jr. Myths of Mississippi's Rural Landscape: Change and Challenge. In A Sense of Place: Mississippi; Prenshaw, P.W., McKee, J.O., Eds.; University of Mississippi Press: Jackson, MS, USA, 1979; pp. 189-215.

95. Berry, J.M.; Portney, K.E. Mobilizing Minority Communities: Social Capital and Participation in Urban Neighborhoods. Am. Behav. Sci. 1997, 40, 632-644.

96. Malecki, E.J. Digital development in rural areas: Potentials and pitfalls. J. Rural Stud. 2003, 19, $210-214$. [CrossRef]

97. Dutta-Bergman, M. Access to the internet in the context of community participation and community satisfaction. New Media Soc. 2005, 7, 89-109. [CrossRef]

98. Boase, J. The Consequences of Personal Networks for Internet Use in Rural Areas. Am. Behav. Sci. 2010, 53, 1257-1267. [CrossRef]

99. Collins, J.; Wellman, B. Small Town in the Internet Society: Chapleau is No Longer an Island. Am. Behav. Sci. 2010, 53, 1344-1366. [CrossRef]

100. Scott, M.; Gallent, N.; Gkartzios, M. The Routledge Companion to Rural Planning; Routledge: New York, NY, USA, 2019; pp. 1-642.

101. Salamon, S. Newcomers to Old Towns: Suburbanization of the Heartland; University of Chicago Press: Chicago, IL, USA, 2003; pp. 1-245.

102. Izenberg, J.M.; Mujahid, M.S.; Yen, I.H. Health in changing neighborhoods: A study of the relationship between gentrification and self-rated health in the state of California. Health Place 2018, 52, 188-195. [CrossRef]

103. Bernard, J.; Šafr, J. The other disadvantaged neighbourhood: Income related effects of living in rural peripheries. Hous. Stud. 2018, 34, 946-973. [CrossRef]

104. Lichter, D.T.; Brown, D.L. Rural America in an urban society: Changing special and social boundaries. Annu. Rev. Sociol. 2011, 37, 565-592. [CrossRef]

105. Versey, H.S. A tale of two Harlems: Gentrification, social capital, and implications for aging in place. Soc. Sci. Med. 2018, 214, 1-11. [CrossRef]

106. Li, S.; Mao, S.; Du, H. Residential mobility and neighbourhood attachment in Guangzhou, China. Environ. Plan. A Econ. Space 2019, 51, 761-780. [CrossRef]

107. Dillman, D.A. Mail and Internet Surveys: The Tailored Design Method Update with New Internet, Visual, and Mixed-Mode Guide, 2nd ed.; John Wiley \& Sons: New York, NY, USA, 2007; pp. 1-544.

108. Brown, R.B.; Xu, X.; Barfield, M.A.; King, B.G. Community Experience and the Conceptual Distinctness of Rural Community Attachment and Satisfaction: A Measurement Model. Res. Community Sociol. 2000, 10, 425-444.

109. Cope, M.R.; Flaherty, J.; Young, K.D.; Brown, R.B. Olympic boomtown: The social impacts of a one-time mega-event in Utah's Heber Valley. Sociol. Spectr. 2015, 35, 136-160. [CrossRef]

110. Erickson, L.D.; Call, V.R.; Brown, R.B. SOS—satisfied or stuck, why older rural residents stay put: Aging in place or stuck in place in rural Utah. Rural Sociol. 2012, 77, 408-434. [CrossRef]

111. Erickson, L.D.; Sanders, S.R.; Cope, M.R. Lifetime stayers in urban, rural, and highly rural communities in Montana. Popul. Space Place 2018, 24, e2133. [CrossRef] 
112. Kelly, D.K. Community Attachment, Religious Participation, and Quality of Life Satisfaction among Adults Involved in Civic Participation. J. Hum. Behav. Soc. Environ. 2013, 23, 561-572. [CrossRef]

113. Kulig, J.C.; Stewart, N.; Penz, K.; Forbes, D.; Morgan, D.; Emerson, P. Work setting, community attachment, and satisfaction among rural and remote nurses. Public Health Nurs. 2009, 26, 430-439. [CrossRef]

(C) 2020 by the authors. Licensee MDPI, Basel, Switzerland. This article is an open access article distributed under the terms and conditions of the Creative Commons Attribution (CC BY) license (http://creativecommons.org/licenses/by/4.0/). 